The Making of Our Bodies, Ourselves

NEXT WAVE

New Directions in Women's Studies A series edited by Inderpal Grewal, Caren Kaplan, and Robyn Wiegman 


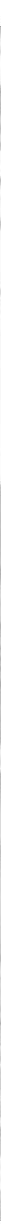




\section{THE MAKING OF}

\section{Our Bodies, Ourselves}

\section{HOW FEMINISM TRAVELS ACROSS BORDERS}

Kathy Davis

DUKE UNIVERSITY PRESS $*$ Durham and London 2007 
(C) 2007 DUKE UNIVERSITY PRESS * All rights reserved * Printed in the United States of America on acid-free paper $@ *$ Designed by C. H. Westmoreland * Typeset in Warnock Pro with Gill Sans display by Tseng Information Systems, Inc. * Library of Congress Cataloging-in-Publication Data appear on the last printed page of this book. 
For my mother, Jan Davis, who taught me the value of a good book 
